\title{
17
}

\section{A Modern Extension - Vickrey and Mirrlees}

David Ricardo and Henry George had proposed a tax that was designed to prevent the distortion of factor or commodity prices. However, both Great Minds had acknowledged that monopolies can equally distort the economy. Frank Ramsey had demonstrated how a commodity tax on the product of monopolies can also enhance public finances while simultaneously correcting some monopoly distortions. However, Henry George's $100 \%$ land tax proved impossible to implement politically, while Ramsey's tax, by contrast, was difficult to implement economically.

By the 1920s in the United States, and earlier in Great Britain, the public sector was beginning to rely increasingly heavily on the revenues from income tax. However, this tax, while relatively simple to implement, had the unfortunate effect in that it acted as a disincentive to increase one's income. Since most taxpayers earn income through their labor effort, such an earned income tax can result in decreased effort. If income per unit of effort is also proportional to one's skill, then a progressive income tax would then presumably discourage the efforts of the most productive. William Vickrey and James Mirrlees set about to create an income tax that would not have this unfortunate disincentive. In doing so, they also created an entirely new field of study, beyond their native public finance, for which many Nobel Memorial Prizes would later be awarded - to them, to Joseph Stiglitz, and to others. 